\title{
KELAYAKAN HIDUP PETANI DITINJAU DARI PENDAPATAN USAHATANI PADI SAWAH YANG MENGGUNAKAN SISTEM SUBAK PADA SUBAK PURA SARI DI KOTA BAUBAU
}

\author{
Antasalam Ajo ${ }^{1)}$ dan Kadek Wardita ${ }^{2)}$ \\ Program Studi Agribisnis, Fakultas Pertanian Univ. Muhammadiyah Buton \\ Relawan Subak Pura Sari Kota Baubau \\ e-mail: antasalampk@yahoo.com
}

\begin{abstract}
The most important thing for farmers is the life feasibility guarantee of farming holding. Because this is the most fundamental measure of a farming activity. Therefore, the efforts of farmers so that farming activities that have been able to fulfill their life's needs in a decent way continues to be important issues and become attention to the future. At the Balinese Hindu community Subak system is maintained since long because it is able to lift the welfare level of farmers. This system regulates life among farmers, as irrigation is done fairly and evenly, discussing planting time, and the type of rice to be planted. If there is a breach, the ceremony is determined by the ceremonies of the citizen or ritual held in the temple. This research aims to measure the life feasibility of farmers based on the income level of rice farmers who implement Subak system at Subak Pura Sari in Baubau Town. The results showed that the life feasibility of farmers was achieved because the average farmer's income was above the regional minimum wage (UMR) in southeast Sulawesi, which amounted to IDR 2,002,625 per month in 2017. With total admission IDR 21,930,000 minus total cost IDR Rp $9,162,648$, then big farmer income is IDR 12,767,352 per planting season in the form of rice or IDR 3,191,838 per month.
\end{abstract}

Keywords: life feasibility, subak system, farming income

\begin{abstract}
Abstrak
Hal paling penting bagi petani adalah adanya jaminan kelayakan hidup dari usatatani yang di milikinya. Sebab ini adalah ukuran paling mendasar dari suatu kegiatan usahatani. Karena itu, upaya petani agar kegiatan usahatani yang digeluti mampu memenuhi kebutuhan hidupnya secara layak terus menjadi isu penting dan menjadi perhatian hingga masa mendatang. Pada masyarakat Hindu Bali sistem Subak dipertahankan sejak lama karena mampu mengangkat tingkat kesejahteraan petani. Sistem ini mengatur kehidupan bersama di antara petani, seperti irigasi dilakukan secara adil dan merata, membicarakan penetapan waktu tanam, dan jenis padi yang akan ditanam. Bila ada pelanggaran, maka sanksinya ditentukan melalui upacara warga atau ritual yang dilaksanakan di Pura. Penelitian ini bertujuan mengukurkelayakan hidup petani berdasarkan tingkat pendapatan petani padi sawah yang melaksanakan sistem Subak pada Subak Pura Sari di Kota Baubau. Hasil penelitian menunjukkan bahwa kelayakan hidup petani telah tercapai karena pendapatn petani rata-rata berada di atas besaran upah minimum regional (UMR) di Sulawesi Tenggara yaitu sebesar Rp 2.002.625 per bulan pada tahun 2017. Dengan total penerimaan $R p$ 21.930.000 dikurangi total biaya $R p \operatorname{Rp} 9.162 .648$, maka besar pendapatan petani adalah Rp 12.767 .352 per musim tanam dalam bentuk beras atau Rp 3.191.838 per bulan.
\end{abstract}


Kata kunci: Kelayakan hidup, sistem subak, pendapatan usahatani

\section{Latar Belakang}

\section{PENDAHULUAN}

Kelayakan hidup yang diperoleh dari usahatani dari sisi petani merupakan hal yang penting. Salah satunya terkait dengan tujuan pembangunan pertanian yakni bagaimana mewujudkan kesejahteraan di kalangan petani, sehingga hasil usahatani mampu memenuhi berbagai kebutuhan hidup petani dan keluarganya. Apabila petani sejahtera, petani memiliki motivasi kerja sehingga bisa menghasilkan pangan untuk memenuhi kebutuhan pangan masyarakat.

Pengukuran kelayakan hidup petani di sini diukur menggunakan standar Kebutuhan Hidup Layak (KHL) yang biasa dianut untuk mengukur kebutuhan hidup layak tenaga kerja. Standar KHL ini adalah berupa standar kebutuhan yang harus dipenuhi oleh seorang pekerja atau buruh lajang, baik secara fisik, non fisik, dan sosial, untuk kebutuhan 1 (satu) bulan. Hal ini diatur dalamUndang-Undang Nomor 13 Tahun 2003 tentang Ketenagakerjaan, Peraturan Presiden Nomor 78 Tahun 2015 tentang Pengupahan, dan diatur lebih lanjut dalam Peraturan Menteri Ketenagakerjaan Nomor 21 Tahun 2016 tentang Kebutuhan Hidup Layak. Sedangkan komponen-komponennya diatur berdasarkan Keputusan Menteri Tenaga Kerja Nomor 13 Tahun 2012.

Merujuk kepada Peraturan Menteri Ketenagakerjaan Nomor 21 Tahun 2016 tentang Kebutuhan Hidup Layak, Pasal 9 ayat 1,penetapan KHL ditentukan berdasarkan peninjauan komponen dan jenis kebutuhan hidup dengan mempertimbangkan rekomendasi Dewan Pengupahan Nasional. Pada Pasal 10 disebutkan bahwa perhitungan nilai KHL tersebut dilakukan oleh Dewan Pengupahan Provinsi atau Dewan Pengupahan Kabupaten/Kota.

Tabel 1. Komponen Kebutuhan Hidup Layak, 2017

\begin{tabular}{|c|c|c|}
\hline No. & Nama Item & Jumlah Item \\
\hline 1. & Makanan dan minuman & 11 \\
\hline 2. & Sandang & 13 \\
\hline 3. & Perumahan & 26 \\
\hline 4. & Pendidikan & 2 \\
\hline 5. & Kesehatan & 5 \\
\hline 6. & Transportasi & 1 \\
\hline 7. & Rekreasi dan tabungan & 2 \\
\hline & Total & 60 \\
\hline
\end{tabular}

Sumber: Lampiran Permenakertrans RI Nomor 13 Tahun 2012 (diringkas)

Terkait kebutuhan hidup petani yang layak, atas dasar pertimbangan Upah Minimum Regional, merupakan salah satu cara untuk menilai bahwa apakah pendapatan usahatani telah memenuhi kelayakan hidup petani atau belum, berdasarkan aturan resmi atau baku yang berlaku tersebut.

Tabel 1. Memperlihatkan komponen Produksi kebutuhan yang harus dipertimbangkan dalam memenuhi setiap kebutuhan hidup petani secara layak yang ditetapkan setiap 5 (lima) tahun.

kebutuhan yang harus dipertimbangkan dalam memenuhi setiap kebutuhan hidup petani secara layak yang ditetapkan setiap 5 (lima) tahun. 
Usaha mewujudkan petani yang sejahtera adalah bagian penting dari pembangunan pertanian. Sebaimana Lynn (2003), mengatakan bahwa proses pembangunan adalah dengan menambah produksi pertanian dan meningkatkan produktivitas usaha berupa penggunaan modal dan skill untuk memperbesar campur tangan manusia.

Sebagaimana diketahui bahwa sebagai makanan pokok masyarakat Indonesia dan Kota Baubau khususnya, maka beras butuh penanganan yang serius dan terpadu. Diperlukan peran pemerintah secara baik dari berbagai proses yang ada. Mulai dari kegiatan penyediaan bibit unggul, pupuk, sarana irigasi, obat-obatan, kredit produksi, kelembagaan, pemasaran, hingga sistem yang berlaku dalam masyarakat.

Peran-peran ini terkait dengan upaya peningkatan pendapatan petani khususnya peningkatan produktivitas, yakni jumlah panen per luas lahan dalam waktu satu musim tanam.Data menunjukkan bahwa luas panenpadi sawah di Kecamatan Bungi sebagai pusat petani padi sawah pada beberapa tahun terakhir dapat dilihat pada Tabel 2.

Tabel 2. Perkembangan Luas Tanam dan Produktivitas Petani Padi Sawah di Kecamatan Bungi Kota Baubau Tahun 2014-2016

\begin{tabular}{|r|c|c|r|}
\hline Tahun & Luas Panen (Ha) & Produksi (Ton) & Produktivitas (Ton/Ha) \\
\hline 2014 & 2.335 & $12.842,5$ & 5.5 \\
\hline 2015 & 2.214 & 12.177 & 5.5 \\
\hline 2016 & 2.016 & $11.289,6$ & 5.6 \\
\hline
\end{tabular}

Sumber: Badan Statistik Kota Baubau 2016

Petani sebagai pelaku agribisnis berperan penting meningkatkan produktivitas usaha sendiri. Menurut Mosher (1985) bahwa petanilah yang harus mempelajari dan menerapkan metode-metode baru yang diperlukan dalam rangka membuat usahataninya menjadi produktif. Petanilah yang menanam, memelihara dan memetik hasil pertaniannya sehingga petani harus memanfaatkan setiap perkembangan itu dengan baik.

Soekartawi (1989) juga menyebutkan bahwa tindakan yang dilakukan adalah bagaimana memperoleh keuntungan yang lebih besar dengan menekan biaya produksi yang sekecil-kecilnya. Prinsip ini perlu dijadikan pegangan bagi petani sehingga tercapai keuntungan yang lebih baik dengan menekan biaya sekecil-kecilnya.

Yudiarini dan kawan-kawan (2014) menyebutkan bahwa subak di Bali telah eksis sejak 10 abad yang lalu, dan hingga kini memberikan pelayanan kepada anggotanya, dan hal ini menunjukkan kemampuan subak memerankan dirinya sebagai suatu sistem irigasi yang berwatak sosio-kultural. Sebab ini sehingga sistem subak tetap dipertahankan oleh masyarakat Bali termasuk yang berusahatani padi sawah di luar Pulau Bali seperti di Kota Baubau. Hingga sekarang dianggap merupakan salah satu cara yang tetap dilestarikan untuk menciptakan kesejahteraan bagi petani padi sawah.

\section{Rumusan Masalah}

Rumusan masalah yang dikemukakan adalah apakah kelayakan hidup petani telah terpenuhi berdasarkan besar pendapatan petani dari usaha padi sawah dengan sistem Subak pada Subak Pura Sari di Kota Baubau.

\section{Tujuan Penelitian}


Adapun tujuan penelitian adalah mengetahui kelayakan hidup petani berdasarkan besar pendapatan usaha tani yang menggunakan sistem Subak pada Subak Pura Sari di Kota Baubau.

\section{Manfaat Penelitian}

Berdasarkan penelitian ini, manfaat yang diperoleh adalah mengetahui tercapainya standar kebutuhan hidup layak (KHL) bagi petani padi sawah dan memberikan tambahan pengetahuan tentang manfaat yang didapatkan oleh petani bila menerapkan sistem subak pada usahataninya.

\section{METODE PENELITIAN}

\section{Waktu dan Lokasi Penelitian}

Penelitian dilaksanakan di Kota Baubau pada masyarakat petani padi sawah Bali yang terdapat di Kelurahan Ngkari-Ngkari pada periode waktu Juni sampai Juli 2016. Alasan lokasi ini dipilih karena di lokasi ini satu-satunya masyarakat petani menggunakan sistem subak di Kota Baubau.

\section{Analisis Data}

Analisis data dilakukan secara kuantitatif yaknimentransfer data, mengedit data, lalu diinterpretasi secara deskriptif. Sedangkan untuk menghitung jumlah pendapatan usahatani padi sawah menggunakan rumus dari Mubyarto (2003), yakni:

$\mathrm{I}=\mathrm{TR}-\mathrm{TC}$

Dimana: $\mathrm{I}=$ pendapatan $($ income $)$

$\mathrm{TR}=$ total penerimaan $($ total revenue $)$

$\mathrm{TC}=$ total biaya (total cost) yang terdiri dari biaya tetap dan biaya variabel

Rumus (1) ini digunakan untuk mengetahui besar pendapatan yang diterima oleh petani di akhir kegiatan dengan asumsi semua hasil produksi dinilai dalam bentuk uang Rupiah.

Sedangkan untuk mengetahui apakah pendapatan yang diterima petani telah memenuhi standar Kebutuhan Hidup Layak (KHL) pada tahun 2017 atau belum adalah dengan membandingkan antara pendapatan yang diterima oleh petani padi sawah dengan besaran Upah Minimun Regional (UMR) yang telah ditetapkan oleh pemerintah Provinsi Sulawesi Tenggara.

Syarat perbandingan:

- Bila besar pendapatan petani padi sawah ini di atas UMR, maka petani hidup layak

- Bila besar pendapatan petani padi sawah di bawah UMR, maka petani tidak hidup layak.

\section{HASIL DAN PEMBAHASAN}

\section{Gambaran Umum Wilayah}

Pusat persawahan di Kota Baubau berada di Kelurahan Ngkari-Ngkari Kecamatan Bungi ini memiliki permukaan dataran rendah 525 Ha dan berbukit-bukit 750 Ha. Lahan ini dimanfaatkan oleh masyarakat untuk sektor pertanian, perkebunan, dan peternakan. Musim atau iklimnya hampir sama dengan daerah lain di Indonesia, yaitu musim hujan dan musim kemarau. Musim hujan terjadi selama 8 bulan dan 4 bulan untuk musim kemarau dalam 1 tahun. Rata-rata curah hujan $2500 \mathrm{~mm}$ per tahun.

Data monografi kelurahan, menyebutkan bahwa jumlah penduduk pada tahun 2016 adalah 2.293 jiwa. Jumlah tersebut terdiri dari 1.159 jiwa laki-laki dan 1.134 jiwa perempuan, 
serta 612 kepala keluarga (KK). Tingkat pendidikan masyarakat Bali di Kota Baubau umumnya didominasi oleh lulusan sekolah menengah ke bawah.Bahkan ada sebagian tidak menamatkan sekolah terakhir yang ditempuh. Dari data profil Kelurahan Ngkari-Ngkari Tahun 2016, hanya 3,7\% penduduk Hindu Bali yang berpendidikan sarjana ke atas, dan sebesar 96,3\% yang berpendidikan SD, SMP, dan SMA atau sederajat.

Mata pencaharian didominasi oleh petani, dan buruh tani. Dari profil Kelurahan Ngkari-Ngkari (2016) jumlah petani adalah 1.024 orang atau 44,66 \% penduduk. Yang lain sisanya antara lain sebagai buruh tani, pegawai negeri sipil, pedagang keliling, montir, dan anggota POLRI. Tingkat kesejahteraan keluarga berdasarkan profil kelurahan bervariasi. Untuk keluarga prasejahtera sebanyak 105 keluarga atau 17,16 \%. Sedangkan jumlah keluarga sejahtera 3 sebanyak 450 keluarga atau 73,53\%. Angkatan kerja yang masih menganggur sebesar 1.270 orang.

\section{Identitas Petani Responden}

Petani padi sawah yang dijadikan reponden sebanyak 25 orang petani. Identitas yang dilihat sebagai faktor-faktor yang mempengaruhi dalam pengelolaan usahatani meliputi umur, pendidikan, pengalaman usahatani, luas lahan, dan jumlah tanggungan keluarga.

\section{Umur petani.}

Umur petani yang dikelompokkan dalam usia produktif sebanyak 19 petani atau $76 \%$. Untuk usia non produktif sebanyak 6 petani atau $24 \%$. Artinya, sebagian besar petani Bali (Hindu) masih dapat mengembangkan berbagai usaha untuk meningkatkan usahataninya. Sedangkan sisanya dipandang penting untuk digantikan oleh orang lain.

\section{Pendidikan.}

Dari sisi pendidikan juga bervariasi, namun masih kurang yang berpendidikan sarjana ke atas. Petani yang tamat SMP sebanyak 10 orang atau $40 \%$, tamat SMA ada 14 orang atau $56 \%$, dan sarjana atau S-1 sebanyak 1 orang atau $4 \%$. Di sini petani perlu meningkatkan lagi tingkat pendidikannya, atau paling tidak pendidikan untuk anggota keluarganya. Sebab dengan pendidikan yang lebih baik, maka kesadaran pengembangan diri dan penguasaan atas ilmu dan teknologi akan lebih maju dibandingkan dengan pendidikan yang rendah.

\section{Jumlah tanggungan keluarga.}

Jumlah tanggungan yang besar akan mendorong petani harus bekerja lebih keras, karena besarnya biaya yang harus ditanggung perlu diimbangi oleh pendapatan usahatani yang diperoleh. Soehardjo dan Patong (1984) menyebut tanggungan keluarga sebagai banyaknya anggota keluarga yang harus ditanggung langsung atau tidak langsung. Dari hasil pengumpulan data, jumlah tanggungan keluarga petani terdiri dari 20 orang petani atau $80 \%$ memiliki tanggungan 4-5 orang dan sisanya atau $20 \%$ petani menanggung 1-3 orang. Ini berarti jumlah tanggungan keluarga petani di lokasi penelitian belum terlalu besar.

\section{Pengalaman usahatani,}

Pengalaman usahatani dinyatakan sebagai waktu yang telah ditempuh petani dalam berusahatani, dimana semakin lama bertani maka semakin baik pula kemampuan usahataninya. Sebagian atau sebanyak 12 orang atau $48 \%$ petani telah bertani selama 22-35 tahun sedangkan sebagian besar lainnya yakni 13 orang atau $52 \%$ telah berusahatani selama 8-21 tahun. Informasi ini mengandung pengertian bahwa petani sudah dapat dikatakan berpengalaman disebabkan sebagian di antaranya sudah bertani sejak dalam usia belia.

\section{Deskripsi Usahatani}


Deskripsi usahatani di sini menggambarkan faktor-faktor yang menjadi penentu utama petani dalam meningkatkan pendapatan usahataninya. Deskripsi tersebut terdiri dari luas lahan, benih, produksi, biaya, nilai produksi (penerimaan), dan pendapatan.

\section{Luas lahan.}

Sebagai ibu usahatani (Soehardjo dan Patong, 1984), tanah adalah tempat keluarnya produk melalui proses produksi. Dari hasil penelitian diperoleh bahwa petani responden hanya memiliki maksimal 3 ha luas lahan yang ada, dan paling sedikit sebesa 0,5 ha. Jadi, ada 17 orang petani atau $68 \%$ memiliki luas lahan berkisar 0,5 ha sampai 1,75 ha. Selebihnya, atau $32 \%$ memiliki lahan seluas dalam kisaran antara 1,76 ha hingga 3 ha.

\section{Benih}

Benih pilihan atau unggul, bermutu, dan tahan terhadap berbagai serangan organisme pengganggu tanaman (OPT) seperti hama dan penyakit tanaman adalah syarat mutlak keberhasilan dalam usahatani. Dari hasil penelitian di lokasi didapatkan bahwa petani menggunakan beberapa jenis varietas/benih seperti Cinpari 13 dan Mikonga dengan waktu panen di kisaran 110 hari. Petani rata-rata memiliki luas lahan 1,24 ha dan rata-rata penggunaan benih sebesar 46,28 $\mathrm{kg}$ atau 33,00 kg/ha dengan harga benih Rp 10.000/kg. Data ini memperlihatkan bahwa kebutuhan atas benih disesuaikan dengan luasan lahan yang dimiliki petani.

\section{Jumlah produksi}

Padi sawah petani dengan sistem subak ini berkisar antara 1.000 sampai $2.700 \mathrm{~kg}$ dihasilkan sebanyak 17 petani atau $68 \%$ sedangkan sebanyak 8 orang atau $32 \%$ memproduksi padi sebanyak $2.701-4.400 \mathrm{~kg}$ padi. Hal ini menunjukkan bahwa sebagian kecil saja petani yang memiliki produksi paling banyak $2.700 \mathrm{~kg}$.

Biaya.

Dalam menunjang keberhasilan usahatani juga diperlukan biaya-biaya, baik biaya tetap maupun biaya variabel. Menurut Carter (2009), biaya ini dinyatakan menurut harga pasar yang berlaku, baik yang sudah terjadi maupun yang akan terjadi. Atau Siregar dan kawan-kawan (2013) menjelaskan biaya pengorbanan sumber ekonomi untuk memperoleh barang dan jasa yang diharapkan memberi manfaat sekarang atau masa yang akan datang.

Tabel 3. Biaya Rata-Rata Petani Padi Sawah dengan Sistem Subak di Subak Pura Sari di Kota Baubau Tahun 2017

\begin{tabular}{llr}
\hline & \multicolumn{1}{c}{ Nonis Biaya } & Rata-Rata Biaya (Rp) \\
\hline 1. & Penggarapan lahan & 1.800 .000 \\
\hline 2. & Pencabutan bibit & 360.000 \\
\hline 3. & Penanaman & 1.200 .000 \\
\hline 4. & Pupuk & 1.728 .000 \\
\hline 5. & Obat-obatan & 1.178 .000 \\
\hline 6. & Perawatan & 836.000 \\
\hline 7. & Pajak & 60.000 \\
\hline 8. & Biaya penyusutan & 2.060 .648 \\
\hline & Jumlah & 9.162 .648 \\
\hline
\end{tabular}

\section{Nilai produksi.}

Nilai produksi atau penerimaan adalah jumlah keseluruhan penerimaan petani setelah padi sawah yang dihasilkan dinilai dengan uang dalam satuan yang berlaku. Berdasarkan 
harga setempat, $1 \mathrm{~kg}$ padi dinilai sebesar Rp 8.500. Berdasarkan penelitian terdapat informasi bahwa nilai produksi petani berkisar antara Rp 8.500.000 hingga Rp 37.400.000. Rata-rata nilai produksi yang dihasilkan sebesar Rp 21.930.000.

Biaya-biaya petani padi sawah di lokasi penelitian digunakan untuk penggarapan lahan, penanaman, pembelian pupuk dan obat-obatan, penyediaan bibit, dan lain-lain (Tabel 3). Rata-rata biaya yang dikeluarkan petani responden dalam memproduksi padi sawah sebesar Rp 9.162.648.

Pendapatan petani.

Sesuai Rumus 1, bahwa pendapatan petani yang merupakan pengurangan dari total penerimaan dengan total biaya. Jadi, hasil Rp 21.930.000 dikurangi Rp Rp 9.162.648 adalah $\mathrm{Rp}$ 12.767.352. Inilah hasil rata-rata yang berhasil didapatkan oleh petani padi sawah yang menggunakan sistem subak di Kota Baubau.

Kelayakan hidup petani.

Dengan per musim rata-rata empat bulan, maka besar pendapatan petani perbulan adalahRp 12.767.352 dibagi 4 adalah Rp 3.191 .838 per bulan. Berdasarkanbesar upah minimum regional (UMR) yang berlaku di Sulawesi Tenggara Tahun 2017 yaitu sebesar Rp 2.002.625 per bulan, maka petani padi sawah yang menerapkan sistem subak memenuhi standar hidup layak.

Tabel 4. Perbandingan Pendapatan Petani Padi Sawah dengan Sistem Subak dengan Upah Minimum Regional (UMR) di Kota Baubau, 2017

\begin{tabular}{lccl}
\hline No. & $\begin{array}{c}\text { Pendapatan Petani } \\
(\text { Rp/Bulan) }\end{array}$ & $\begin{array}{c}\text { Upah Minimum } \\
\text { Regional (UMR) (Rp) }\end{array}$ & Kesimpulan \\
& 3.191 .838 & & \\
\hline 1. & & 2.002 .625 & $\begin{array}{l}\text { Petani Hidup } \\
\text { Layak }\end{array}$ \\
\hline
\end{tabular}

\section{KESIMPULAN DAN SARAN}

Dari hasil penelitian dapat disimpulkan bahwa pendapatan rata-rata usahatani padi sawah yang menerapkan sistem subak di Kota Baubau sebesar Rp 12.767.352 dalam bentuk beras permusim tanam, atau Rp 3.191 .838 per bulan. Dibandingan dengan besar Upah Minimum Regional (UMR) Tahun 2017 yang sebesar Rp 2.002.625, maka petani memenuhi syarat untuk dikatakan hidup layak.

Sebagai saran dalam penelitian ini adalah meskipun sistem subak dianggap terbaik bagi petani, namun peningkatan kemampuan usahatani yang lebih baik lagi bagi para petani, seperti penerapan teknologi, peningkatan kualitas sumberdaya manusia, kelembagaan petani, serta adanya kebijakan pemerintah sangat dibutuhkan. Keterlibatan berbagai pihak terkait lainnya dalam mendorong peningkatan kesejahteraan petani juga sangat diperlukan.

\section{DAFTAR PUSTAKA}

Biro Pusat Statistik Kota Baubau, 2016. Kota Baubau dalam Angka 2016. Baubau. Carter, W.K. 2009. Akuntansi Biaya 'Cost Accounting'. Salemba Empat. Jakarta. Kelurahan Ngkari-Ngkari, 2016. Profil Kelurahan Ngkari-Ngkari 2016. Baubau. Lynn, Stuart R. 2003. Economic Development: Theory and Practice for a Divided World. Prentice Hall. New Jersey. 
Mosher, A.T. 1985. Menciptakan Struktur Pedesaan Progresif. Disunting oleh Rochim Wirjoniodjojo. Yasaguna. Jakarta.

Mubyarto. 2003. Pengantar Ekonomi Pertanian. LP3ES. Jakarta.

Peraturan Menteri Ketenagakerjaan Nomor 21 Tahun 2016 tentang Kebutuhan Hidup Layak. Peraturan Presiden Nomor 78 Tahun 2015 tentang Pengupahan.

Siregar, Baldric, Suripto, Bambang. 2013. Akuntasi Biaya.Salemba Empat. Jakarta.

Soehardjo A. dan Dahlan Patong, 1984. Sendi-Sendi Pokok Ilmu Usahatani. Universitas Hasanuddin, Ujung Pandang.

Soekartawi. 1989. Prinsip Dasar Ekonomi Pertanian: Teori dan Aplikasi. Rajawali Press. Jakarta.

Undang-Undang Nomor 13 Tahun 2003 tentang Ketenagakerjaan, Suwarto. 2012. Produktivitas Lahan Usaha Tani sesuai Kelembagaan Lahan (Suatu Tinjauan Teoritis). Jurnal of Rural and Development, 3 (1).

Yudiarini, N., K. Budi Susrusa, dan NW. Sri Astiti. 2014. Dampak Pengembangan Agribisnis pada Subak Terhadap Pendapatan Rumah Tangga Petani (Kasus di Subak Guama Kecamatan Marga Kabupaten Tabanan). Jurnal Manajemen Agribisnis Vo. 2 No. 1 Mei 2014. Fakultas Pertanian Universitas Udayana. Bali. 